EESTI NSV TEADUSTE AKADEEMIA TOIMETISED. Y KOIDE

BIOLOOGILINE SEERIA, 1956, Nr. 2

ИЗВЕСТИЯ АКАДЕМИИ НАУК ЭСТОНСКОИ ССР. ТОМ V

СЕРИЯ БИОЛОГИЧЕСКАЯ. 1956, № 2

\title{
ВЫРОЖДЕНИЕ КАРТОФЕЛЯ В ЭСТОНСКОЙ ССР И МЕРОПРИЯТИЯ ПО БОРЬБЕ С НИМ
}

\section{Б. Х. НУРМИСТЕ,}

кандидат сельскохозяйственных наук

Несмотря на то, что природные условия Әстонии вполне благоприятны для возделывания картофеля, уровень урожаев этой важной пищевой, кормовой и технической культуры до настоящего времєни остается недопустимо низким. Наряду с недостатками в агротехнике, одной из важных причин, препятствующих повышению урожайности картофеля, является широкое распространение его болезней. Вследствие того, что картофель размножаєтся вегетативно, многие его болезни легко передаются от одного поколения к другому и происходит их накопление.

Из болезней картофеля в Эстонской ССР так же, как и в других Прибалтийских республиках и северо-западных областях РСФСР, наибольший ущерб наносят фитофтора и болезни вырождения. Разработка эффективной системы мероприятий для борьбы с ними, несомненно, поможет значительно повысить урожаи картофеля.

Что касается фитофторы, то решающей мерой борьбы против нее является возделывание фитофтороустойчивых сортов. Поскольку такие сорта уже имеются, например, районированные недавно сорта Иыгеваской Государственной селєкционной станции Тальвик и Олев, то устранение почти ежегодных эпифитотий фитофторы представляет собой вопрос чисто организационного порядка.

Борьба же с болезнями вырождения картофеля является уже более сложной задачей. Работа селекционеров по выведению устойчивых к вырождєнию сортов не дала пока необходимого результата. До сих пор не достаточно выяснено, какие условия внешней среды на севере имеют решающее влияние на устойчивость картофельного растения и на развитие болезней. Кроме того, внедрєнию в практику уже известных мер борьбы препятствует то обстоятельство, что практическим работникам недостаточно знаком характер этих заболеваний* и что некоторые формы вы-

* Особенно характерным для болезней вырождения картофеля является следующее: 1) проявляющееся в данном году заболевание в основном представляет собой последействие предыдущих периодов вегетации; 2) вырожденное растение, как правило, дает вырожденное клубневое потомство; 3) не существует выздоровления больного растения, но, так как болезнь, кроме уменьшения размеров клубней, снижает и их ч и л о в гнезде, то в условиях, не вызывающих новых заболеваний, происходит постепенное снижение процента больных особей, т. е. происходит естественный отбор и сорт как таковой может выздороветь. 
рождения часто недооцениваются вследствие слабой внешней выраженности их. Например, на первый взгляд трудно бывает представить, что широко распространенная легкая форма вырождения, так называемая мозаика или крапчатость (неравномерное распределєние хлорофилла в тканях листа), обусловливает значительные недоборы урожая картофеля. В действительности же крапчатые растения дают урожаи в среднем на $10-15 \%$ ниже здоровых.

Основными формами вырождения, кроме вышєуказанной крапчатости, являются морщинистость (деформация листвы, часто сопровождаемая некротическими пятнами и общей подавленностью роста) и полосчатость (некротические полосы и пятна на листьях и стеблях, отмирание нижних листьев), причем степень вредоносности этих заболеваний в значительной мере зависит от сорта и условий питания растения. Несмотря на то, что морщинистость и полосчатость считаются обычно наиболее вредоносными, в условиях Әстонии наибольший вред наносит все же обыкновенная крапчатость, что вызвано чрезвычайно широким распространением последней. Например, у районированного сорта Йыгева Пиклик 20\% растений нередко бывает крапчатыми, а у сорта Мажестик даже 90\%.

Общий убыток, причиняємый картофелеводству ЭССР болезнями вырождения, более значителен, чем это предполагалось раньше. По нашим многочисленным долголетним наблюдениям и специальным опытам недобор урожая позднеспелых и среднеспелых сортов картофеля в ЭССР, обусловленный болєзнями вырождения, составляет в среднем не менее $5 \%$. Снижение урожая ранних сортов, сильнее страдающих от вырождения, достигает $10 \%$. В некоторых случаях, чаще всего в условиях пригородной зоны, потери урожая от вырождения составляют 50 и больше процентов. В целом по всей территории республики вследствие этих болезней ежегодно теряются десятки тысяч тонн картофеля.

Относительно причин болезней вырождения картофеля мнения исследователей, как известно, сильно расходятся. Часть из них придерживается взгляда, что вырождение есть следствие непосредственного влияния некоторых неблагоприятных для картофельного растения условий выращивания. По мнению же другой части исследователей, вырождение представляет собой результат инфекционных вирусных заболеваний. Несмотря на то, что за рубежом этот вопрос очевидно разрешен в пользу вирусной теории, фактический материал, представленный обеими этими школами, все же не позволяет сделать обобщающего вывода. Все говорит за то, что на картофеле встречаются оба типа вырождения, т. е. как экологический (неинфекционный), так и вирусный (инфекционный). Соответственно тому, какой тип вырождения в определенном ареале возделывания картофеля был доминирующим и тем самым служил объектом исследования, образовалось обобщающее заключение по этому вопросу. С одной стороны, было бы бесполезно отрицать существование вирусов растений, в том числе и вирусов картофеля, т. е. существование определєнных паразитирующих белков. Но с другой стороны, следует учитывать, что влияние неблагоприятных условий выращивания, если оно превышает приспособляемость растения, может вызывать независящие от инфекции функциональные расстройства. Ввиду того, что механизм подобных функциональных расстройств связан с азотным и белковым обменом веществ, каковым является и репродукция вирусов, то по внешнему виду эти два типа вырождения часто не отличаются друг от друга.

Нашими исследованиями, проводившимися в течение 15 лет на Иыгеваской Государственной селекционной станции и в Институте растениєводства Академии наук Эстонской ССР, бесспорно установлено, что почти все болезни вырождения сортов картофеля ЭССР являются инфекци- 
онными. До настоящего времени выявлено шесть различных вирусов, являющихся возбудителями болезней; при этом наибольшее значение имеют вирусы $x, y, A$ и закручивания листьев. Лишь немногие формы вырождения, как, например, так называемый кудряш и некоторые формы деформации листвы на первых этапах селекции картофеля (особенно на сеянцах), видимо относятся к экологическому типу. В том факте, что вырождение картофеля в Эстонии обусловлено главным образом инфекционными началами - вирусами, нет ничего особенного, так как здесь на картофеле обитают такие типичные переносчики вирусов, какими являются тли Doralis rhamni, D. frangulae, Aulacorthum pseudosolani. Myzodes persicae. Особенного внимания заслуживает факт обнаружения в местной фауне опасного переносчика вирусов - персиковой тли Myzodes persicae, которая в некоторые годы в большом количестве встречается на картофеле в окрестностях городов и поселков. Жизнедеятельность тлей не вызывает ежєгодного массового вырождения картофеля лишь потому, что тли обычно появляются относительно поздно - к концу июля - и инфекция не захватывает клубней (особенно у поздних и среднепоздних сортов, составляющих основные массивы картофеля в Эстонии). Однако во всех известных до настоящего времени случаях, где вырождение принимало необычные размеры, обнаруживалось раннее и массовое появление тлей. Так, например, во время массового распространения болезней вырождения (1939-1941 годы) тли появились уже в середине июня. Ранним появлением тлей и высокой степіенью вырожденности характеризуются также приусадебные участки картофеля в пригородной зоне. Таким образом, хотя и существует непосредственная контактная инфекция, * вырождение картофеля зависит в первую очередь от распространения и численности тлей.

Из сказанного выше следует, что под вырождением картофеля в ЭССР следует понимать действие инфекционных вирусных заболеваний. В связи с этим мероприятия по устранению потерь от вырождения должны быть направлены на борьбу с этими заболеваниями. Спекулятивные, лишенные достаточного основания обобщающие трактовки некоторых представителей экологической школы не могут в местных условиях служить основой при установлении путей борьбы с вырождением картофеля. Особенно это относится к селекции. Исходя в селекционной работе из теории экологического вырождения, можно допустить большие ошибки и нанести вред делу.

По своему существу вирусные заболевания значительно отличаются от грибных и бактериальных заболеваний, в связи с чем систему паразитирующий белок + растение-хозяин нельзя отождєствлять с системой паразитируюший гриб (бактерия) + растение-хозяин.

Вследствие того, что при вирусном заболевании инфекционное начало обитает в протоплазме и в большинстве случаев равномерно распределено в организмє растения, требования этого инфекционного начала в отношении внешних условий совпадают с требованиями растения в значительно бо́льшей мере, чем это имеет место при грибном или бактериальном заболевании. Из этого вытекает немаловажный с точки зрения борьбы с инфекционным вырождениєм картофеля вывод: все мероприятия, способствующие вегетативному росту и тем самым в большинстве случаев повышению урожайности картофеля, способствуют одновременно размножению вируса и наоборот. Поэтому агротехнические мероприятия (своевременно провєденная обработка почвы, удобрение и пр.), которые, например, при грибном заболевании, когда паразит в отношении условий развития растения сохраняет некоторую автономность, позволяют расте-

* При наличии вирусов $x$ н $F$, 
нию-хозяину освободиться от паразита, при общих (системных) вирусных заболеваниях, какими являются болезни вырождения картофеля в ӘССР, не могут дать положительного эффекта.

Этот принцип подтверждается исслєдованиями многих авторов. Подтверждается это и специальными опытами, проведенными в Институте растениеводства Академии наук ЭССР, которые показали, например, что совместное внесение азотистого и известкового удобрений дополнительно к фосфорно-калийному, повышало урожай здоровых растений на $50 \%$ и одновременно снижало урожай морщинистых растений на $30 \%$ по сравнению с контролем (одни фосфорно-калийные удобрения без извести и азота). В этих же опытах медное удобрение (в виде $\mathrm{CuSO}_{4}$ ), точно так же способствуя развитию здоровых растений и повышая их урожай, вызывало вместе с тем более быстрое размножение вируса $y$ в искусственно зараженных растениях и его проникновение в клубни. В противоположность этому большие дозы бора, ведущие к угнетению роста здоровых растений, задерживали размножение вируса и его переход в клубни зараженных растений. С данными наших опытов согласуются и наблюдения в производстве: депрессия морщинистых растений на хорошо удобренных участках всегда выражена более резко, чем на менее удобренных.

Из всего сказанного должно быть ясно, что вырожденный картофель не способен использовать благоприятные условия питания и что врєдоносность болезней вырождения увеличивается с повышением фона удобрений. В том случае, если бы весь картофель состоял из морщинистых растений, влияние обильного удобрения было бы отрицательным и значительно понижало бы урожай. Подобноє влияние высокого фона удобрений нельзя, конечно, обобщать. В тех условиях, в которых фактор инфекции отпал бы (например, в случае отсутствия переносчиков) и количество вырожденных (морщинистых) растений имелось бы в умеренном количестве, обильное удобрение способствовало бы ускорению отбора в пользу здоровых растений, так как последние, далеко превосходя по урожайности морщинистые растения, повышали бы удельный вес здоровых растений в по сл е ду ющ и х р е п о д у ц и я х. Высокий фон удобрений может. с одной стороны, вызывать снижение урожая, а с доугой стороны. способствовать естественному отбору в сторону оздоровления. Опрєделяющим здесь оказывается то обстоятельство, в какой мере картофель заражен вызывающим вырождение вирусом и какова частота инфекции.

Распространенность инфекционного вырождения в пределах сорта не определяется лишь частотой инфекции, а зависит также от реакции сорта на тот или другой вирус. В зависимости от того, какое значение в опрєделенных конкретных условиях имеет инфекция (т. е. какова частота инфекции и передаваемость инфекционного начала в клубни) и каким являетгя действие болезни на отдельное растение (т. е. как велика депрессия больного растения в урожае - в количестве и весе клубней), создается та или иная степень вырожденности данного сорта. Во взаимодействии этих двух факторов и заключается в основном сущность инфекционного вырождения картофеля. Исходя из этого взаимодействия, становится понятным, почему, например, обыкновенная крапчатость, мало сказывающаяся на урожае, распространяется быстрее, чем сильно действующая на урожай морщинистость. Становится также понятным, почему морщинистость встречается реже на картофеле, растущем в открытом полє, чем на картофеле на защищенных от ветра приусадебных огородах, где условия для развития переносчиков вирусов особенно благоприятны.

Взаимодействием частоты инфекции и депрессии зараженного растения объясняются не только явления вырождения в их формах и динами- 
ке, а одновременно определяются и основные направления борьбы. Әтими направлениями являются: 1) борьба с инфекцией и 2) соответственное регулирование условий питания картофеля, которое в случае инфекции препятствовало бы проникновению инфекционного начала в клубни. Исходя из этих принципов, постараемся вывести и охарактеризовать некоторые меры борьбы.

Как при всех инфекционных болезнях растений, так и при вирусном вырождении картофеля элементарным требованием является ликвидация или изоляция очагов инфекции. Подобными очагами инфекции являются в первую очередь выродившиеся растения. Удаление пораженных вирусами растений представляет собой, таким образом, необходимую меру, начиная с первых этапов селекции и кончая семенным участком любого хозяйства - производителя картофєля. Однако опыт показывает, что эффективность этого мероприятия понижается по мере повышения процента больных растений.* В связи с этим на семенном участке колхоза было бы трудно при помощи лишь этого приема устранить ошибки селекции и выращивания элиты. Точно так же и другое известное в практике мероприятие - выбраковка мелких клубней из посадочного материала не всегда дает удовлетворительный эфффект, так как при некоторых заболеваниях; например, обыкновенной крапчатости, размеры клубней снижаются незначительно. Выбраковку в поле и отбор клубней следует рассматривать лишь как вспомогательные приємы, ускоряющие процесс естественного отбора и дающие эффект только в случае умеренного развития тяжелых форм вырождения (скручивание листьев, морщинистость).

Очагом инфекции может быть (или становиться с течением времени), помимо больного растения, и сорт картофеля в целом. Соответственно указанному выше взаимодействию между частотой инфекции и депрессией у слабореагирующего сорта могут стать зараженными все его особи, вследствие чего весь сорт в целом может обратиться в резерватор вируса. В ӘССР имеются такие сорта, которые, несмотря на сплошное заражение, все же удержались в производстве (например, Ранняя роза, Мажестик, Аллерфрюэсте Гельбе, Вяйке верев и ряд других). Практически эти сорта, несмотря на их более или менее нормальную внешность, сплошь заражены $x$-, $A$ - или же $y$ - вирусом. Вполне ясно, что подобные скрытые вирусоносители, находясь в непосредственной близости или в смеси с сильнореагирующими сортами, рєзко повышают при наличии переносчиков частоту инфекции и вызывают необычайно быстрое вырождение последних. Главным образом этим и объясняется высокая степень вырождения картофеля в сортовых смесях индивидуальных огородов и в коллекциях, где, впрочєм, тяжелые формы вырождения вызываются различными смешанными инфекциями $(x+A$, $x+F$ и др.).

Изоляция или ликвидация очагов инфекции, какими являются сплошь зараженные сорта картофеля, является сложным организационным мероприятием. Под ликвидацией очагов инфекции следует понимать не только вытеснение вышеуказанных сортов из индивидуальных огородов, но также и пространственную изоляцию семенных посевов картофеля от картофеля производственных массивов и от индивидуальных огородов как возможных очагов инфекции. Наконец, если быть последовательными, то следовало бы включить в эту систему мероприятий также и борьбу за сортовую чистоту и за сокращение числа сортов, возделываемых в одном хозяйстве, Многосортность на ограниченной территории является уже сама по себе предпосылкой для образования опасных очагов инфекции.

* При большом удельном весе больных растений заражение, по всей вероятности, ироисходит уже до прополки. 
Ввиду того, что при сильном прорастании посадочного материала некоторые вирусы передаются от больных клубней здоровым при соприкосновении ростков, существенное значениє для предупреждения контактной инфекции имеет создание благоприятных условий хранения семенного картофеля.

Что же касается химической борьбы с тлями - переносчиками вирусов, то в большинстве случаев этот приєм в семеноводстве картофеля нерационален, главным образом из-за постоянного поступления тлей с различных других видов растений. Многократное же опрыскивание ядохимикатами оправдывает себя лишь при защите ценного селекционного материала.

Ответственные задачи по борьбе с инфекционным вырождением картофеля падают на селекцию. Неправильная установка в этой области рано или поздно обнаружится в производственной практике. Селекционеру прежде всего должно быть ясно, что именно следует понимать под вирусоустойчивым сортом. Из вышеизложенного должно было бы вытекать, что под вирусоустойчивым сортом в условиях ӘССР нельзя подразумевать слабореагирующий сорт. ${ }^{*}$ Вследствие того, что слабореагирующий на данный вирус сорт рано или поздно сплошь заражается этим вирусом, урожайность сорта уменьшается значительно больше, чем в результате тяжелых форм вырождения при редком их появлении. В конечном рєзультате легко реагирующий сорт в принципе не отличается от скрытого вирусоносителя и становится постоянной угрозой для других сортов. Таким образом, легко представить, какую роль в распространении болезней вырождения может играть селекционер. Отрицая, например, вирусы растений и принимая вызванную вирусом слабую крапчатость листвы за случайную экологическую депрессию, селекционер в виде нового сорта может дать производству огромный очаг инфекционного начала.** Для предупреждения таких возможностей в число задач селекции должны были бы входить: 1) непрерывный контроль за содержанием вирусов в гибридах и 2) определение реакции нерспективных гибридов на главнейшие в местных условиях вирусы. Цель селекции картофеля в отношении вирусных заболеваний в местных условиях можно кратко сформулировать следующим образом: вывести сорта, реагирующие возможно более резко в отношении главнейших вирусов, причем необходимо, чтобы обусловленные этими вирусами болезни распространялись в пределах сорта как можно медленнее. Для определения реакции селекционного материала можно без особых затруднений применить метод искусственной инфекции. Әтот же метод, при соответственном его применении, дает одновременно некоторое представление и о скорости распространения болєзни: чем меньше степень передачи вируса при искусственной инфекции клубням, тем медленнее, по всей вероятности, будет происходить и процесс вырождения в полевых условиях.*** Произведенная в течение ряда

* Это положение не следует, однако, обобщать. В некоторых южных районах возделывания картофеля, где частота инфекции огромна и картофель может даже сплошь заражаться тяжелыми формами вырождения, следовало бы, может быть, отдать предпочтение сортам, слабо реагирующим на переносимые тлями вирусы.

** При легкой форме заболевания особенно ярко выражается коренное различие между вирусной и экологической формами вырождения: свойство сорта слабо реагировать на неблагоприятные условия жизни является безусловно положительным по сравнению со свойством слабо реагировать на вирус и давать возможность сплошному заражению.

*** Распространение заболевания в пределах данного сорта определяется н е т л ько степенью заражаемости клубней, но зависит и от других, пока еще точно не установленных факторов. Поэтому некоторые гибриды, несмотря на сплошную зараженность клубней при искусственной инфекции, могут в естественных условиях все же оказаться устойчивыми. 
лет оценка Йгеваских гибридов в отношении устойчивости к вирусам показала, что сорта, оказавшиєся устойчивыми в лабораторных условиях, бывали без исключения такими же и в поле.*

Опыт Йгеваской Государственной селекционной станции показывает, что реагирующие резко на вирус $y$ сорта, при медленном темпе их вырождения, можно получить от межвидового скрещивания Sol. tuberosum c Sol. demissum. Полученный этим способом районированный сорт Олєв можно в отношении некоторых форм вируса $y$ считать даже барьерным (сверхчувствительным). К сожалению, среди производных Sol. demissum, выведенных на Иыгеваской госселекстанции, пока не удалось найти барьерных форм к вирусу $x$. В условиях же Эстонии, где вирус $x$ широко распространен, барьерныє сорта имели бы большое практическое значение.

Если в области селекции в отношении инфекционного вырождения основным является борьба с инфекцией, то в области семеноводства картофеля главное внимание должно быть обращено на регулирование условий питания растений, позволяющее получить здоровый и в то же время биологически полноценный посадочный материал.**

В данном случае необходимо признать, что в области семеноводства картофеля пока нет полной ясности. Хотя и имеются многочисленные наблюдения, но тем не менее тєоретически обоснованные обобщения пока еще отсутствуют. Более того, сделанные в свое время неправильные обобщения устойчиво сохраняются в сознании многих семеноводов. Одно из обобщений подобного рода тєсно связано с вопросом борьбы с вирусными заболеваниями картофеля. Это ложное положение гласит, что урожай семенного картофеля с единицы площади должен быть по возможности выше, или, как принято выражаться, должен происходить с высокого агрофона. Так как под понятием «высокий агрофон» некоторые семеноводы обычно понимают «фон высоких доз удобрений», то в практике с сєменных участков весьма часто получается биологически неполноценный семенной материал. На высоком агрофоне часто получаются семенные клубни, которые в производственных условиях дают менее урожайные и болєе восприимчивые к различным заболеваниям растения, чем это обычно свойственно сорту. Но с точки зрения инфекционного вырождения особенно важно то обстоятельство, что в семеноводстве часто односторонне и в чрезмерных количествах применяются азотное и калийное удобрения. Эти удобрения удлиняют период вегєтации, при чем инфекционное начало в большей мере проникает в клубни. Кроме того, азотное удобрение, влияя на белковый обмен веществ, по всей вероятности, способствует и размножению вируса. Наряду с удобрениєм, немаловажным фактором в семеноводстве картофеля являются норма и способ посадки, которые, воздействуя на условия питания, могут замедлять или же ускорять образование клубней, то есть способствовать проникновению вируса в клубни или же несколько препятствовать этому. Наконец, на семенной клубєнь не могут не оказывать воздействия состояние почвы и степень ее обработанности, так как степень аэрации почвы может значительно влиять на срок образования клубней и на все послєдующие процессы, связанные с распространением инфекции. В соответствии с вышеуказанным принципы агротехники семеноводства картофеля можно было бы сформулировать следующим образом:

\footnotetext{
* Полное соответствие было установлено в отношении $y$-вируса, например, для сортов Лембиту и Вирулане.

** При рассмотрении этих двух понятий (здоровый и биологически полноценный) опять-таки выявляется различие между экологическим и вирусным вырождениями: при экологическом вырождении эти понятия обычно совпадают, в случае же вирусного заболевания здоровое растение может оказаться биологически неполноценным.
} 
1. Интенсивный уровень обработки почвы (причем этот уровень может даже не оправдываться увеличєнием урожая).

2. Умеренные (учитывая воздействие азота) дозы органических удобрений; скромные дозы калийного удобрения без содержания хлора; высокие или очень высокие дозы фосфорного удобрения. Для характеристики систємы удобрения можно даже сказать: одностороннее удобрение фосфором при минимальном применении калия и азота.

3. Густой, рядовой способ посадки* (в условиях Эстонии около $70-80$ тысяч растений на га) с целью получения бо́льшего числа не очень крупных клубней и более раннего клубнеобразования.

К этим ускоряющим клубнеобразование приемам могло бы в определенных конкретных условиях добавляться скашиваниє ботвы картофеля до окончания периода вегетации.

Цель разработанной на этих принципах агротехники заключается не только в защите семенного клубня от инфекции, но одновременно и в сохранении его биологически полноценным. То обстоятельство, что сєменной клубень при подобной агротехнике может остаться незрелым и мелким, не снижает его качества. Это подтверждается многими фактами, указывающими на своеобразное явлєние компенсации в урожаях семенного и производственного картофеля: мелкий семенной клубень, образовавшийся при умеренном питании, дает на высоком фоне удобрения производственного картофеля более высокий урожай, чем крупный семенной клубєнь, выращенный при обильном удобрении. Тот давно известный в производственной практике факт, что чужой семенной материал по урожайности превосходит местный, или другими словами, что снизившуюся урожайность постоянно возделываемого в определенной местности сорта картофеля можно резко повысить путем перенесения єго в другие условия выращивания, - оказывается по существу тем же явлением компенсации.

Семеноводство представляет собой, как известно, важную подготовительную фазу, которая должна обєспечить максимальную производительность данной культуры в следующей репродукции. Особенно действителен этот принцип в отношении такой вегетативно размножаемой культуры, какой является картофель. Для обеспечения высокого урожая производственного картофеля посадочный материал должєн иметь определенную предпосылку, так называемый физиологический потенциал, позволяющий в соответствии с возможностями сорта максимально использовать хорошие условия питания производственного фона. Едва ли имеется подобный потенциал у чрезмерно крупных, «перекормленных» обильным азотным и калийным удобрениями клубней, нз которых, напримєр, нередко состоит элита Иыгеваской селекционной станции.** В этом отношении мы даже не имеем права упрекать селекционную станцию. Ведь плановые заказы на элиту даются в то н н а х. «Тонны» же легче всего получить посредством азотных и калийных удобрєний. Одно лишь это соображение должно убедить нас в том, что семеноводство должно существенно отличаться от выращивания картофеля для продовольственных целєй и что основой продуцирования семенного картофеля должно служить ч и сл о клу б н ей с единицы площади (вместо принятого в настоящее время количества в тоннах с единицы площади). Следовательно, потребность

* Квадратно-гнездовая посадка не оправдает себя в семеноводстве картофеля также при прополке больных растеннй (вырожденных, пораженных черной ножкой), так как в таком случае при обнаружении в гнезде одного больного растения пришлось бы удалить целиком все гнездо, т. е. 2-3 растения вместо одного.

** В элите картофеля Иыгеваской селекционной станции клубни весом 150-200 грамм составляют 20 и более процентов. 
в перєоценке некоторых основных положений в семеноводстве картофеля диктуется не только необходимостыю проведения борьбы с инфекционным вырождением, но и необходимостью получения биологически полноценного семенного материала.

Из вышеизложенного вытекает, что при освоєнии в селекции и семеноводстве картофеля определенных принципов, применяя одновременно на практике известные общеорганизационные мероприятия, возможно успешно предупредить вырождение картофеля и вместе с тем значительно повысить урожайность этой культуры в Әстонской ССР. Однако необходимо признать, что подобная система борьбы требует значительного применения рабочей силы (например, прополка больных растений) и постоянного надзора за выполнением всех мероприятий. Базирующаяся исключительно на профилактике система борьбы безусловно являєтся трудоемкой. То обстоятельство, что против вирусных заболеваний картофеля до настоящего времени нет более эффективных и не столь трудоемких мер борьбы, обусловлено недостаточным знанием биологичєской сущности вирусов растений. До тех пор, пока не разрешен вопрос происхождения вирусов (доклеточный ли это организм или паразитирующий белок, отщепленный от общего белкового комплекса высшего организма) и не установлено соотношениє между экологическим и инфекционным формами вырождения, следует ради повышения урожайности картофеля на больших производственных массивах проводить на всех этапах селекции и семеноводства указанную выше сложную систему мер борьбы с вырождением, направленную одновремєнно и на получение биологически полноценного семенного посадочного материала.

Эстонский научно-исследовательский институт земледелия и мелиорации
Поступила в редакцию 31 V 1956

\section{ЛИТЕРАТУРА}

1. Б р а ун Х., Вырождение картофеля, Сельское хозяйство за рубежом, № 1, 1954, стр. $181-183$.

2. Клапп Е., Связь между условиями выращивания (обусловленными почвой н удобрением), количеством персиковой тли и семенными качествами картофеля, Сельское хозяйство за рубежом, № 1, 1954, стр. 184-195.

3. Купрев и ч В. Ф., Физиология больного растения в связи с общими вопросами паразитизма, Изд. АН СССР, 1947.

4. Линник Г. Н., О причинах вырождения картофеля, Ботанический журнал, № 4, 1955, стр. 528-541.

5. Мишустин Е. Н. и Перд овск а я М. М., Микроорганизмы и самоочищение почвы, Изд. АН СССР, 1954, стр. 489-495.

6. Рожалин Л. В., Вырождение картофеля и несостоятельность теории заразности мозаичных вирусных болезней картофеля, Вестник по овощам и картофелю, $1,15,1940$.

7. Р ожалин Л. В., Исследования вырожденного семенного картофеля, Научный стчет ИКХ за 1941-1944 годы, 1947.

8. Р ыжков В. А., Фитопатогенные вирусы, Изд. АН СССР, 1946.

9. Сухов К. С., Проблема вырождения картофеля, Труды Института генетики, 16 , 1948 , стр. $161-178$.

10. Фаворов А. М. и Котов А. Ф., Летняя посадка картофеля, Сельхозгиз, 1952, стр. 302.

11. Ф ом юк М. К., Поражаемость картофе́ля готикой в зависимости от условий питания, Агробиология, № 2, 1953, стр. 85-92. 


\title{
KARTULI KIDUMINE EESTI NSV-S JA TEMA TORJE
}

\section{B. NURMISTE,}

\author{
põllumajandusteaduste kandidaat
}

\section{Resümee}

Kartulisaakide madala taseme Eesti NSV-s tingivad puuduliku agrotehnika kõrval kartulihaigused - lehemädanik ja kidumishaigused. Lehemädaniku probleem lahendub uute haiguskindlate sortide levikuga. Kidumishaiguste osas pole sordiaretus landnud oodatud tulemusi. Praktikasse ei ole rakendatud teadaolevaid tõrjevõtteid. Alahinnatakse kidumishaiguste kahjustust.

Peamised Eestis ettetulevad kartuli kidumise vormid on mosaiiklaiksus, kimarlehisus ja kärbumishaigus. Oma laialdase leviku tõttu põhjustab mosaiiklaiksus kõige suuremaid saagikadusid. Kõige rohkem esineb kidumishaigusi individuaal-aedades linnalähedases tsoonis. Eriti kannatavad varavalmivad sordid.

Peaaegu kõik kartulil esinevad kidumisnähud Eestis on infektsioonilised, kusjuures haigusetekitajatest on tähtslamateks $x$-, $y$-, $A$ - ja mosaiikse keerdlehisuse viirus. Mitteinfektsioonilist (ökoloogilist) kidumist on leitud Eestis kartuliseemikute hulgas, kus neid välistunnuste poolest viirushaigetest ei saa eristada. Putuksiirutajate hulgas on Eestis esindatud ka Myzodes persicae. Kidumishaiguste massiline esinemine on ühenduses lehetäide massilise ja varajase ilmumisega eelneval aastal. Tiheda sideme tõttu parasiidi ja peremeestaime vahel kõik tegurid, mis soodustavad kartulitaime kasvu (ja seega enamasti tõstavad mugulasaaki), soodustavad ka viiruse paljunemist ja tema jaotumist kogu taimkehas. Kõrge kidumisastme puhul rikkalik väetus mõjub negatiivselt.

Infektsioonilise kidumise levik antud sordi piirides sõltub infektsioonisagedusest ja depressiooniastmest, mida kutsub esile infektsioon. Selle tõttu kergeltreageerivad kartulisordid haigestuvad kiiremini kui raskeltreageerivad. Viimaste juures loodusliku valikuprotsessi tulemusena kidumisaste jääb madalamaks.

Põhilised tõrjeprintsiibid on: 1) võitlus infektsiooni vastu ja 2) taime toitumistingimuste selline reguleerimine, mis takistaks infektsioonilise algme jõudmist mugulatesse.

Tavialised infektsioonitakistavad tõrjevõtted - haigete taimede õigeaegne väljakitkumine ja peenemate mugulate eraldamine külvisest - on oma olemuselt loodusliku valikuprotsessi kiirendajad ja pääsevad mõjule vaid raskete kidumisvormide puhul nende mõõdukal esinemisel. Suurt praktilist tähendust Eestis infektsioonikolletena omavad mõned läbini (100\%-liselt) nakatatud sordid, millel haigus väliselt sageli ei avaldu. Nende sortide väljatõrjumise eest tuleb võidelda samavõrd, kui tuleb võidelda sordipuhtuse eest ja kitsamal territooriumil kasvatatavate sortide arvu piiramise eest. Paljusordilisus on eelduseks ohtlike infektsioonikollete tekkimisel. Seemnekartuli õige säilitamine, mis väldib tema ärakasvamise, takistab $x$-viiruse levikut. Keemiline tõrje lehetäide vastu on ratsionaalne vaid hinnalise aretusmaterjali kaitsmise puhul.

Ókoloogilise koolkonna seișkohtade ühekülgne omaksvõtmine sordiaretuses on ohtlik. Sordiaretuse sihiks infektsioonilise kidumise osas peaks kohalikes tingimustes olema: salada tähtsamate viiruste suhtes võimalikult teravalt reageerivad kartulisordid, kusjuures neist viirustest põhjustatavad haigused leviksid nende sortide piirides aeglaselt. Kergeltreageerivate kartulisortide puhul jääb alati püsima oht, et nad ıja jooksul läbini haiges- 
tudes märkamatult muutuvad viirusekandjateks. Vastavalt kohandatud kunstliku infektsiooni meetodi abil saab aretusmaterjali hinnata niihästi reaktsiooni kui ka kidumistempo seisukohalt. Kasutades sordiaretuses metsikut liiki Solanum demissum, on Jõgeva Riiklikus Sordiaretusjaamas saadud kartulivorme, mis teatavate $y$-viiruse alaliikide suhtes osutusid ülitundlikeks ja seega vastupidavateks.

Kartuli eliitseemnekasvatuses kasutatakse liiga kõrgeid kaali- ja lämmastikväetise norme, mis pikendavad vegetatsiooni ja soodustavad sellega mugulate nakatumist viirustega. Lisaks sellele näitavad katsed ja tähelepanekud, et suuremõõduline kartulimugul ei oma seda füsioloogilist potentsiaali, mida nõutakse külviselt ja pole seega ka bioloogiliselt täisväärtuslik. Seemnekartuli tootmise aluseks peaks seepärast olema mitte niivõrd tsentnerite arv, kuivõrd m u g u l a t e a r v pindühikult. Vastavalt sellele põhimõttele võiks seemnekartuli agrotehnikat iseloomustada järgmiselt: 1) väga intensiivne mullaharimine ja kultuuri hooldamine; 2) tugevad fosforväetise, mõõdukad orgaanilise väetise ja tagasihoidlikud kloori mittesisaldava kaaliväetise annused; 3) tihe reaviisiline kasvatamine, arvestusega $70-80$ tuhat taime hektarile. Neile mugulamoodustamist kiirendavaile agrotehnika elementidele võiks teatavates konkreetsetes tingimustes lisanduda kartulipealsete niitmine enne vegetatsiooni lōppu. Sellise agrotehnika juures oleks välditud niihästi mugulanakkuse kui ka «ületoitumise» oht.

Kartuli kidumishaiguste tõrjesüsteem on veel raskepärane. Niikaua kuni pole lahendatud taimeviiruste päritolu küsimus ja sellega ühenduses selgitatud seos ökoloogilise kidumise ja viirushaiguste vahel, pole aluseid tõhusama tõrjesüsteemi väljatöötamiseks.

Eesti Maaviljeluse ja Maaparanduse

Teadusliku Uurimise Instituut
Saabus toimetusse

31. V 1956

\title{
KARTOFFELABBAU UND SEINE BEKÄMPFUN(i IN DER ESTNISCHEN SSR
}

\author{
B. NURMISTE,
}

\section{Zusammenfassung}

Als Ursachen der niedrigen Kartoffelerträge in der Estnischen SSR sind neben unzulänglicher Agrotechnik die Kartoffelkrankheiten - PhytophthoraFäule und Abbaukrankheiten - anzusehen. Die Lösung des PhytophthoraProblems hängt davon $\mathrm{ab}$, in welchem Masse die neuen resistenten Kartoffelsorten Verbreitung finden. Bezüglich der Abbaukrankheiten sind in der Resistenzzüchtung die erhofften Erfolge ausgeblieben. In der Praxis werden die schon längst bekannten Bekämpfungsmassnahmen kaum angewendet. Die von den Abbaukrankheiten verursachten Schäden werden unterschätzt.

Die wichtigsten in Estland vorkommenden Abbauformen sind: das gewöhnliche Mosaik, Kräuselmosaik und Strichelkrankheit. Infolge seiner allgemeinen Verbreitung verursacht das gewöhnliche Mosaik die grössten Ertragsausfälle. Am häufigsten sind die Abbaukrankheiten der Kartoffel in der Umgebung der Städte vertreten. Insbesondere leiden unter Abbau die frühreifenden Sorten. Praktisch genommen sind fast alle in Estland 
vorkommenden Abbaukrankheiten infektiös. Von den Krankheitserregern sind hauptsächlich die Viren $x, y, A$ und $K \mathrm{zu}$ verzeichnen. Abbauformen nichtinfektiöser Natur sind in Estland unter Kartoffelsämlingen gefunden worden. Den äusseren Merkmalen nach sind diese ökologischen Abbauformen von den Viruskranken nicht zu unterscheiden. Unter den virusübertragenden Blattlausarten ist in Estland auch Myzodes persicae vertreten. Für die «Abbaujahre ist die frühe und massenhafte Verbreitung der Blattläuse charakteristisch. Infolge eines engen Verbundenseins zwischen Parasit und Wirtspflanze bewirken im Falle einer Viruskrankheit alle wachstumsbefördernden (und somit meistens auch ertragserhöhenden) Aussenfaktoren das beschleunigte Vermehren des Viruseiweisses und seine gleichmässige Verteilung im ganzen Pflanzenkörper. Im Falle eines hohen Abbaugrades wirkt reichliche Düngung negativ.

Die Ausbreitung des infektiösen Abbaues innerhalb einer gegebenen Kartoffelsorte hängt von der Infektionshäufigkeit und von dem durch die Infektion hervorgerufenen Depressionsgnade ab. Demzufolge verseuchen auf die Virusinfektion schwachreagierende Kartoffelsorten schneller als schwerreagierende. Bei den letzten wird der Abbaugnad durch den stets wirkenden natürlichen Auswahlprozess bedeutend herabgesetzt.

Die Hauptgrundsätze der Bekämpfung sind: 1) Verhinderung der Infektion und 2) entsprechendes Regulieren der Ernährungsbedingungen der Kartoffelpflanze, wodurch die Ansteckung der Knollen erkrankter Stauden gehemmt wird.

Die gewöhnlichen infektionsverhindernden Bekämpfungsverfahren - das Ausroden erkrankter Pflanzen aus den Saatkartoffelbeständen und das Entfernen kleiner Knollen aus dem Saatgut - sind dem Wesen nach nur Beschleuniger der natürlichen Auswahl und kommen nur bei gemässigtem Vorkommen schwerer Abbauformen zur Geltung. Als riesige Infektionsherde sind in Estland einige gänzlich (100\%-ig) mit Viren verseuchte Kartoffelsorten zu beachten, bei denen der Abbau sich äusserlich kaum merklich macht. Neben Verdrängung der gänzlich verseuchten Sorten ist die Beachtung der Sortenreinheit und womöglich die Einschränkung der Sortenanzahl im engeren Anbaubezirk ebenfalls von grosser Wichtigkeit. Vielfältigkeit des Kartoffelsortiments ist schon an sich eine Voraussetzung zur Bildung gefährlicher Infektionsherde. Durch die richtigen Aufbewahrungsbedingungen des Saatguts, die das Keimen der Knollen unterdrücken, wird zugleich die Verbreitung des $x$-Virus verhütet. Die chemische Bekämpfung der Blattläuse ist nur im Flalle der Beschützung des wertvollen Züchtungsmaterials als rationell anzusehen.

Das kritiklose Hinnehmen der Standpunkte der ökologischen Schule ist in der Züchtung zu vermeiden. Das Ziel der Resistenzzüchtung kann in hiesigen Verhältnissen als folgend formuliert werden: bezüglich der allerwichtigsten Viren möglichst scharfreagierende Kartoffelsorten zu erhalten, bei denen der Verseuchungsprozess sich möglichst langsam labspielt. Bei den schwachreagierenden Sorten wird immer die Gefahr bestehen bleiben, dass sie in kurzer Zeit vollständig verseuchen und sich unbemerkt zu Virusträgern lausbilden. Mittels entsprechend angepasster Methode der künstlichen Infektion kann das Züchtungsmaterial hinsichtlich der Reaktion als auch der Verseuchungsgeschwindigkeit abgeschätzt werden können. Durch die Benutzung der wilden Art Solanum demissum ist es lauf der Reichsstation für Saatzucht in Jögeva gelungen neue Kartoffelsorten zu bekommen, die sich gegen gewisse Stämme des Virus $y$ als überempfindlich und somit als feldresistent erwiesen.

Im Anbau der Kartoffelelite werden Kali- und Stickstoffdünger in zu hohen Dosen verwendet, wodurch die Vegetationsperiode verlängert und 
die Knolleninfektion begünstigt wird. Hinzu kommt, dass die bei reichlicher Düngung sich bildenden übergrossen Kartoffelknollen erfahrungsgemäss nicht das vom Saatgut erforderliche füsiologische Potenzial besitzen und somit lauch biologisch minderwertig sind. In der Produktion der Saatkartoffel müsste deswegen neben Zentnerzahl auch die Knollenzahl pro Hektar in Betracht gezogen werden. Dementsprechend könnte man die Agrotechnik der Saatkartoffel als folgend charakterisieren: 1) äusserst intensive Bodenbearbeitung; 2) starke Dosen des Phosphordüngers, mässige Verwendung des organischen Düngers und zurückhaltende Dosen des chlorverlustigen Kalidüngers; 3) Anbau in Reihenanordnung bei grosser Legedichte - 70 bis 80 Tausend Knollen pro Hektar. Diesen, die Knollenbildung beschleunigenden Massnahmen könnte in gewissen konkreten Fällen das vorzeitige Abmähen des Krautes hinzu kommen. Bei solcher Agrotechnik wäre sowohl die Knolleninfektion als auch die «Uberfütterungsgefahr» vermieden.

Das Bekämpfungssystem mit den Abbaukrankheiten ist schwerfällig. Solange jedoch die Herkunftsfrage der Pflanzenviren ungelöst bleibt, und der Zusammenhang zwischen Abbauerscheinungen infektiöser und ökologischer Art nicht festgestellt ist, wird man kaum ein effektiveres Bekämpfungssystem ausarbeiten können.

Institut für Ackerbau

und Melioration der Estnischen SSR
Eingegangen am 31. Mai 1956 